\title{
Fatty acid and sugar compositions, and nutritional value of five wild edible mushrooms from Northeast Portugal
}

\author{
Lillian Barros $^{\text {a }}$, Paula Baptista ${ }^{\text {a }}$, Daniela M. Correia ${ }^{\mathrm{a}}$, Susana Casal ${ }^{\mathrm{b}}$, \\ Beatriz Oliveira ${ }^{b}$, Isabel C.F.R. Ferreira ${ }^{\mathrm{a}, *}$ \\ ${ }^{a}$ CIMO/Escola Superior Agrária, Instituto Politécnico de Bragança, Campus de Santa Apolónia, Apartado 1172, 5301-855 Bragança, Portugal \\ ${ }^{\mathrm{b}}$ REQUIMTE/Serviço de Bromatologia, Faculdade de Farmácia da Universidade do Porto, Rua Aníbal Cunha 164, 4099-030 Porto, Portugal
}

Received 10 November 2006; received in revised form 31 January 2007; accepted 21 March 2007

\begin{abstract}
The chemical composition and nutritional value of five wild edible mushroom species (Agaricus arvensis, Lactarius deliciosus, Leucopaxillus giganteus, Sarcodon imbricatus, Tricholoma portentosum) commonly consumed in the Trás-os-Montes region of Northeast Portugal was determined. Chemical composition evaluation included moisture, total oil content, crude protein, ash, carbohydrates, and nutritional value determination. The macronutrient profile in general revealed that the wild mushrooms were rich sources of protein and carbohydrates, and had low amounts of fat. On the basis of the proximate analysis, it can be calculated that an edible portion of $100 \mathrm{~g}$ of these mushrooms provides, on average, $28 \mathrm{kcal}(118 \mathrm{~kJ})$. The analysis of fatty acid composition, performed by gas-liquid chromatography coupled to a flame ionization detector, allowed the quantification of fifteen fatty acids. Unsaturated fatty acids and, in particular, oleic and linoleic acids, were predominant. The composition in individual sugars was also determined by high performance liquid chromatography coupled to a refraction index detector, mannitol and trehalose being the most abundant sugars.
\end{abstract}

(C) 2007 Elsevier Ltd. All rights reserved.

Keywords: Wild edible mushrooms; Chemical composition; Fatty acid composition; Sugar composition; Nutritional value

\section{Introduction}

More than 2000 species of mushrooms exist in nature; however, less than 25 species are widely accepted as food and only a few have attained the level of an item of commerce (Lindequist, Niedermeyer, \& Julich, 2005; Smith, 1972). Wild mushrooms are becoming more and more important in our diet for their nutritional (Breene, 1990; Crisan \& Sands, 1978; Manzi, Gambelli, Marconi, Vivanti, \& Pizzoferrato, 1999), organoleptic (Maga, 1981) and pharmacological (Bobek \& Galbavy, 1999; Bobek, Ginter, Jurcovicova, \& Kunia, 1991; Bobek, Ozdyn, \&

\footnotetext{
* Corresponding author. Tel.: +351 273 303219; fax: +351 273325405 . E-mail address: iferreira@ipb.pt (I.C.F.R. Ferreira).
}

Kuniak, 1995) characteristics. The consumption of wild edible mushrooms is increasing due to a good content of proteins and trace minerals (Ogundana \& Fagade, 1982; Senatore, 1990; Thimmel \& Kluthe, 1998). Some investigations have even contended that the amino acid compositions of mushrooms are comparable to animal proteins (Fink \& Hoppenhaus, 1958; Gruen \& Wong, 1982), which is particularly important considering that human nutrition has become more complicated since the outbreak of diseases connected with animal meat. Although, the nutritional potential or implications of this gradual replacement of meat with mushroom requires careful examination which involves detailed chemical and biological studies.

Concerning the use of mushrooms as a functional food and as source for the development of drugs and 
nutraceuticals, we have been interested in the evaluation of bioactive properties of wild edible mushrooms from Northeast Portugal, namely antioxidant and antimicrobial activities. For the evaluation of antioxidant properties, the reducing power of mushrooms extracts and their scavenging effects on DPPH (1,1-diphenyl-2-picrylhidrazyl) radicals were studied and correlated with the portion of the mushroom used (cap or stipe) (Ferreira, Baptista, Vilas-Boas, \& Barros, 2007). In a different experiment, we concluded that antioxidant components present in the mushrooms extracts protected the membrane of erythrocytes incubated with AAPH $\left(2,2^{\prime}\right.$-azobis(2-amidinopropane)dihydrochloride), and reduced the extent of $\beta$-carotene destruction by neutralizing the linoleate radical (Barros, Ferreira, Queirós, Ferreira, \& Baptista, 2007). Those and other reports (Valentão, Andrade et al., 2005; Valentão, Lopes et al., 2005) contribute to the valorization of Portuguese mushrooms as antioxidant sources namely, phenolic compounds and organic acids. Mushrooms antimicrobial activity was also evaluated by us and directly correlated with their content of phenols and flavonoids. Different wild edible mushroom species inhibited some medically important microorganisms, suggesting that they are also potential sources of antimicrobial agents (Barros et al., in press).

Besides all the pharmacological properties already available in the literature, there are no reports about the nutritional value and chemical composition of Portuguese mushrooms. Several studies have been carried out on the chemical composition and nutrition quality of edible mushrooms from different countries, particularly on Spanish (Diéz \& Alvarez, 2001), Italian (Manzi, Aguzzi, \& Pizzoferrato, 2001; Manzi, Marconi, Aguzzi, \& Pizzoferrato, 2004), Turkish (Yildiz, Karakaplan, \& Aydin, 1998), Indian (Agahar-Murugkar \& Subbulakshmi, 2005; Longvah \& Deosthale, 1998) and Nigerian (Aletor, 1995; Fasidi, 1996) species. The Northeast of Portugal, due to climatic conditions and flora diversity, is one of the European regions with higher wild edible mushrooms diversity, some of them with great gastronomic relevance. In spite of the immense popularity of this food in the region and their increased exportation to foreign countries (particularly Spain, France and Italy), data regarding the nutritive value of the wild mushroom varieties available in the region are very meagre.

Herein, we report the chemical composition of five wild edible mushrooms (Agaricus arvensis, Lactarius deliciosus, Leucopaxillus giganteus, Sarcodon imbricatus and Tricholoma portentosum), with reference to the contents of dry matter, proteins, fat, carbohydrate and ash. Among the individual components, fatty acid and sugar profiles were obtained by gas-liquid chromatography coupled to a flame ionization detector (GLC/FID) and high performance liquid chromatography coupled to a refraction index detector (HPLC/RI), respectively. On the basis of the samples composition, an estimation of the mushrooms nutritional role was also performed.

\section{Materials and methods}

\subsection{Samples}

Samples of Agaricus arvensis (Schaeff.: Fr.) and Leucopaxillus giganteus (Sowerby) Singer were collected from grassland whereas Lactarius deliciosus (L.) Gray, Sarcodon imbricatus (L.) P. Karst., and Tricholoma portentosum (Fr.) Quél. were collected under live pine trees (Pinus sp.), in Bragança (Northeast of Portugal), in autumn 2005. After collection, the mushrooms were grouped by taxon, airdried in a freeze-drier (Ly-8-FM-ULE, Snijders) and powdered before analysis. Taxonomic identification was made according to several authors (Bon, 1988; Courtecuisse, 1999; Courtecuisse \& Duhem, 1995; Marchand, 19711986; Moser, 1983) and representative voucher specimens were deposited at the herbarium of Escola Superior Agrária of Instituto Politécnico de Bragança. For all the mushroom species three samples were analysed.

\subsection{Chemical composition}

Samples of mushrooms were analysed for chemical composition (moisture, protein, fat, carbohydrates and ash) using the AOAC procedures (1995). The crude protein content $(N \times 4.38)$ of the samples was estimated by the macroKjeldahl method according to Léon-Guzmán, Silva, and López (1997); the crude fat was determined by extracting a known weight of powdered mushroom sample with petroleum ether, using a Soxhlet apparatus; the ash content was determined by incineration at $600 \pm 15^{\circ} \mathrm{C}$. Total carbohydrates were calculated by difference. Total energy was calculated according to the following equations (Manzi, Marconi, Aguzzi, \& Pizzoferrato):

$$
\begin{aligned}
& \text { Energy }(\text { kcal })=4 \times(\text { g protein }+ \text { g carbohydrate }) \\
& +9 \times(\text { g lipid }) ; \\
& \text { Energy }(\mathrm{kJ})=17 \times(\mathrm{g} \text { protein }+\mathrm{g} \text { carbohydrate }) \\
& +37 \times(\mathrm{g} \text { lipid }) .
\end{aligned}
$$

\subsection{Fatty acid composition}

Fatty acids were determined by gas-liquid chromatography with flame ionization detection (GLC-FID)/capillary column based on the ISO 5509 (2000) trans-esterification method. The fatty acid profile was analyzed with a Chrompack CP 9001 chromatograph (Chrompack, Middelburg, Netherlands) equipped with a split-splitless injector, a FID, and a Chrompack CP-9050 autosampler. The temperatures of the injector and detector were $250{ }^{\circ} \mathrm{C}$. Separation was achieved on a $50 \mathrm{~m} \times 0.25 \mathrm{~mm}$ i.d. fused silica capillary column coated with a $0.19 \mu \mathrm{m}$ film of CP-Sil 88 (Chrompack). Helium was used as carrier gas at an internal pressure of $120 \mathrm{kPa}$. The column temperature was $140{ }^{\circ} \mathrm{C}$, for a $5 \mathrm{~min}$ hold, and then programmed to increase to $220^{\circ} \mathrm{C}$ at a rate of $4{ }^{\circ} \mathrm{C} / \mathrm{min}$ and then held for $10 \mathrm{~min}$. 
The split ratio was 1:50, and the injected volume was $1.2 \mu 1$. The results are expressed in relative percentage of each fatty acid, calculated by internal normalization of the chromatographic peak area. Fatty acid identification was made by comparing the relative retention times of FAME peaks from samples with standards. A Supelco (Bellefonte, PA) mixture of 37 FAMEs (standard 47885-U) was used. Some fatty acid isomers were identified with individual standards also purchased from Supelco.

\subsection{Sugar composition}

Free sugars were determined by high performance liquid chromatography coupled to a refraction index detector (HPLC-RI) based on the method used by Harada, Gisusi, Yoneyama, and Aoyama (2004) with minor modifications. Dried powder $(1.0 \mathrm{~g})$ was extracted with $40 \mathrm{ml}$ of $80 \%$ aqueous ethanol at $80^{\circ} \mathrm{C}$ for $30 \mathrm{~min}$. The resulting suspension was centrifuged at $15,000 \mathrm{~g}$ for $10 \mathrm{~min}$. The supernatant was concentrated at $60{ }^{\circ} \mathrm{C}$ under reduced pressure and defatted three times with $10 \mathrm{ml}$ of ethyl ether, successively. After concentration at $40^{\circ} \mathrm{C}$, the solid residues were dissolved in water to a final volume of $5 \mathrm{ml}$. Soluble sugars were determined by using HPLC (Knauer, Smartline system) at $35^{\circ} \mathrm{C}$. The HPLC system was equipped with a Knauer Smartline $2300 \mathrm{RI}$ detector and with a Eurospher 100-5 $\mathrm{NH}_{2}$ column $(4.6 \times 250 \mathrm{~mm}, 5 \mathrm{~mm}$, Knauer $)$. The mobile phase was acetonitrile/deionized water, 7:3 (v/v) at a flow rate of $1.25 \mathrm{ml} / \mathrm{min}$. The results are expressed in $\mathrm{g} / 100 \mathrm{~g}$ of fresh weight, calculated by internal normalization of the chromatographic peak area. Sugar identification was made by comparing the relative retention times of sample peaks with standards. The sugar standards used for identification were purchased from Sigma Chemical Co. (St. Louis, USA): L(+)-arabinose, D(-)-fructose, D(+)-galactose, $\mathrm{D}(+)$-glucose anhydrous, lactose 1-hydrate, maltose 1-hydrate, $\mathrm{D}(+)$-mannitol, $\mathrm{D}(+)$-mannose, $\mathrm{D}(+)$-melezitose, $\mathrm{D}(+)$-melibiose monohydrate, $\mathrm{L}(+)$-rhamnose monohydrate, $\mathrm{D}(+)$-sucrose, $\mathrm{D}(+)$-trehalose and $\mathrm{D}(+)$-xylose.

\section{Results and discussion}

The results of the chemical composition and estimated energetic value obtained for the five mushroom species are shown in Table 1. The moisture ranged from $90.05 \mathrm{~g} / 100 \mathrm{~g}$ of fresh weight in L. deliciosus and $94.90 \mathrm{~g} / 100 \mathrm{~g}$ in $A$. arvensis. Protein was found in high levels and varied between $2.12 \mathrm{~g} / 100 \mathrm{~g}$ in $T$. portentosum and $3.40 \mathrm{~g} / 100 \mathrm{~g}$ in L. giganteus. However, it is known that the protein contents of mushrooms are affected by a number of factors, namely the type of mushrooms, the stage of development, the part sampled, level of nitrogen available and the location (Flegg \& Maw, 1977). Fat ranged from $0.09 \mathrm{~g} / 100 \mathrm{~g}$ in $S$. imbricatus and $0.41 \mathrm{~g} / 100 \mathrm{~g}$ in L. giganteus. The wild mushrooms were rich sources of protein and had low amounts of fat making it an ideal snack material. These high protein and low fat characteristics of the edible wild mushrooms have been previously reported by many workers (Aletor, 1995; Diéz \& Alvarez, 2001; Longvah \& Deosthale, 1998). Carbohydrates, calculated by difference, were also an abundant macronutrient and ranged from $1.91 \mathrm{~g} / 100 \mathrm{~g}$ in $A$. arvensis and $6.26 \mathrm{~g} / 100 \mathrm{~g}$ in $L$. deliciosus. Ash content varied between $0.18 \mathrm{~g} / 100 \mathrm{~g}$ in $A$. arvensis and $0.81 \mathrm{~g} / 100 \mathrm{~g}$ in $T$. portentosum. All the species seem to have a normal chemical composition compared with other edible mushrooms (Agahar-Murugkar \& Subbulakshmi, 2005; Aletor, 1995; Crisan \& Sands, 1978; Diéz \& Alvarez, 2001; Longvah \& Deosthale, 1998; Manzi et al., 1999; Manzi et al., 2001; Manzi et al., 2004). On the basis of the proximate analysis, it can be calculated that an edible portion of $100 \mathrm{~g}$ of these mushrooms provides, on average, $28 \mathrm{kcal}(118 \mathrm{~kJ})$. The highest values are guaranteed by $L$. deliciosus, while A. arvensis give the lowest energy contribution (Table 1 ).

The results for fatty acid composition, total saturated fatty acids (SFA), monounsaturated fatty acids (MUFA), and polyunsaturated fatty acids (PUFA) of the studied mushrooms are shown in Table 2. In general, the major fatty acids found in the studied samples were linoleic acid (C18:2 $n-6)$ and oleic acid (C18:1 n-9), followed by palmitic acid $(\mathrm{C} 16: 0)$. This is in agreement with the results reported for the Indian mushrooms, Schizophyllum commune and Lentinus edodes, in which linoleic $(\sim 65 \%)$, palmitic $(\sim 20 \%)$ and oleic $(\sim 10 \%)$ acids accounted for almost the whole of the fatty acids determined (Longvah \& Deosthale, 1998). Similar observations have been made in other mushrooms (Senatore, Dini, \& Marino, 1988). The fatty acid profile of several

Table 1

Proximate chemical composition (g/100 g of fresh weight) and energetic value of five Portuguese wild edible mushrooms (mean \pm SD; $n=3$ )

\begin{tabular}{|c|c|c|c|c|c|}
\hline & \multicolumn{5}{|l|}{ Mushrooms } \\
\hline & A. arvensis & L. deliciosus & L. giganteus & S. imbricatus & T. portentosum \\
\hline Moisture & $94.90 \pm 0.75$ & $90.05 \pm 0.53$ & $92.43 \pm 0.76$ & $93.89 \pm 0.00$ & $93.05 \pm 0.51$ \\
\hline Total fat & $0.14 \pm 0.00$ & $0.22 \pm 0.00$ & $0.41 \pm 0.02$ & $0.09 \pm 0.01$ & $0.38 \pm 0.02$ \\
\hline Crude protein & $2.87 \pm 0.19$ & $2.96 \pm 0.04$ & $3.40 \pm 0.01$ & $2.35 \pm 0.02$ & $2.12 \pm 0.08$ \\
\hline Ash & $0.18 \pm 0.01$ & $0.51 \pm 0.02$ & $0.65 \pm 0.04$ & $0.29 \pm 0.08$ & $0.81 \pm 0.03$ \\
\hline Carbohydrates & $1.91 \pm 0.24$ & $6.26 \pm 0.15$ & $3.11 \pm 0.21$ & $3.38 \pm 0.03$ & $3.64 \pm 0.16$ \\
\hline Energy (kcal) & $20.38 \pm 1.71$ & $38.86 \pm 0.75$ & $29.73 \pm 1.05$ & $23.73 \pm 0.28$ & $26.46 \pm 1.14$ \\
\hline Energy $(\mathrm{kJ})$ & $86.44 \pm 7.27$ & $164.88 \pm 3.19$ & $125.84 \pm 4.44$ & $100.74 \pm 1.18$ & $111.98 \pm 4.82$ \\
\hline
\end{tabular}


Table 2

Fatty acid composition (\%) of five Portuguese wild edible mushrooms (mean $\pm \mathrm{SD} ; n=3$ )

\begin{tabular}{|c|c|c|c|c|c|}
\hline & \multicolumn{5}{|l|}{ Mushrooms } \\
\hline & A. arvensis & L. deliciosus & L. giganteus & S. imbricatus & T. portentosum \\
\hline C14:0 & $2.34 \pm 0.16$ & $0.48 \pm 0.00$ & $2.70 \pm 0.01$ & $0.27 \pm 0.03$ & $0.13 \pm 0.00$ \\
\hline C15:0 & $0.79 \pm 0.02$ & $0.53 \pm 0.05$ & $0.33 \pm 0.00$ & $1.22 \pm 0.05$ & $0.95 \pm 0.01$ \\
\hline $\mathrm{C} 16: 0$ & $14.55 \pm 0.27$ & $12.08 \pm 0.06$ & $13.46 \pm 0.05$ & $11.14 \pm 0.05$ & $5.60 \pm 0.01$ \\
\hline $\mathrm{C} 16: 1 \mathrm{c}$ & $4.32 \pm 0.22$ & $0.92 \pm 0.03$ & $12.91 \pm 0.05$ & $0.98 \pm 0.01$ & $0.51 \pm 0.03$ \\
\hline $\mathrm{C} 17: 0$ & $0.56 \pm 0.00$ & $0.18 \pm 0.01$ & $0.08 \pm 0.00$ & $0.13 \pm 0.02$ & $0.05 \pm 0.00$ \\
\hline C18:0 & $3.37 \pm 0.23$ & $25.33 \pm 0.06$ & $2.11 \pm 0.02$ & $3.65 \pm 0.11$ & $2.33 \pm 0.01$ \\
\hline C18:1c & $15.46 \pm 1.67$ & $41.26 \pm 0.02$ & $21.09 \pm 0.51$ & $45.06 \pm 0.20$ & $58.36 \pm 0.06$ \\
\hline $\mathrm{C} 18: 2 \mathrm{c}$ & $56.11 \pm 1.49$ & $17.06 \pm 0.23$ & $46.18 \pm 0.48$ & $35.38 \pm 0.38$ & $30.88 \pm 0.08$ \\
\hline $\mathrm{C} 18 \mathrm{sc}$ & $0.19 \pm 0.03$ & $0.26 \pm 0.02$ & $0.09 \pm 0.02$ & $0.16 \pm 0.00$ & $0.40 \pm 0.01$ \\
\hline C20:0 & $0.87 \pm 0.02$ & $0.44 \pm 0.03$ & $0.12 \pm 0.00$ & $0.88 \pm 0.01$ & $0.13 \pm 0.00$ \\
\hline C20:1c & $0.07 \pm 0.02$ & $0.10 \pm 0.00$ & $0.07 \pm 0.01$ & $0.15 \pm 0.01$ & $0.15 \pm 0.00$ \\
\hline C21:0 & $0.15 \pm 0.05$ & $0.11 \pm 0.05$ & $0.07 \pm 0.01$ & $0.08 \pm 0.01$ & $0.06 \pm 0.00$ \\
\hline C22:0 & $0.47 \pm 0.04$ & $0.38 \pm 0.03$ & $0.12 \pm 0.00$ & $0.57 \pm 0.01$ & $0.23 \pm 0.00$ \\
\hline $\mathrm{C} 22 \mathrm{ac}$ & $0.37 \pm 0.04$ & $0.27 \pm 0.09$ & $0.40 \pm 0.01$ & $0.20 \pm 0.07$ & $0.11 \pm 0.02$ \\
\hline C24:0 & $0.37 \pm 0.06$ & $0.60 \pm 0.06$ & $0.27 \pm 0.01$ & $0.13 \pm 0.05$ & $0.08 \pm 0.02$ \\
\hline Total SFA & $23.47 \pm 0.06$ & $40.14 \pm 0.13$ & $19.25 \pm 0.02$ & $18.08 \pm 0.09$ & $9.57 \pm 0.02$ \\
\hline Total MUFA & $19.85 \pm 1.48$ & $42.28 \pm 0.01$ & $34.08 \pm 0.46$ & $46.20 \pm 0.21$ & $59.03 \pm 0.03$ \\
\hline Total PUFA & $56.68 \pm 1.42$ & $17.59 \pm 0.12$ & $46.67 \pm 0.47$ & $35.73 \pm 0.30$ & $31.40 \pm 0.05$ \\
\hline
\end{tabular}

Tricholoma species was already determined and once more, for $T$. portentosum and $T$. terreum, oleic $(\sim 57 \%)$ and linoleic $(\sim 28 \%)$ acid were the main fatty acid constituents, while other fatty acids detected were found only in small amounts (Diéz \& Alvarez, 2001). It is known that linoleic acid is the precursor of 1-octen-3-ol, known as the alcohol of fungi, which is the principal aromatic compound in most fungi and might contribute to mushroom flavour (Maga, 1981). Besides the three main fatty acids already described, 12 more were identified and quantified. Some of them have already been described, but, for different mushroom species and not so exhaustively. PUFA were the main group of fatty acids in $A$. arvensis and L. giganteus, while in L. deliciosus, S. imbricatus and $T$. portentosum, MUFA were the main group. Nevertheless, UFA predominate over SFA for all the studied mushroom species, ranging from $59.9 \%$ to $90.4 \%$. This is consistent with the observations that, in mushrooms, unsaturated fatty acids predominate over the saturated in the total fatty acid content (Diéz \& Alvarez, 2001; Longvah \& Deosthale, 1998; Mauger et al., 2003). Considering total MUFA content, A. arvensis had the lowest value but contained the highest PUFA content, also being the mushroom with the highest value of linoleic acid. $T$. portentosum had the lowest SFA value, and the highest value of oleic acid presenting values in agreement with those published previously (Diéz \& Alvarez, 2001).
Fortunately, trans isomers of unsaturated fatty acids were not detected in the studied mushrooms. A rapidly expanding literature documents the importance of trans fatty acids (TFAs) in human health due to the increased risk of cardiovascular disease where they are negatively correlated with plasma HDL-cholesterol concentration and positively correlated with plasma LDL-cholesterol level (Minamide \& Hammond, 1985). It is also important to point out that, in contrast to other fungi (Diéz \& Alvarez, 2001; Longvah \& Deosthale, 1998), no other fatty acids with an odd number of carbon atoms have been detected in considerable amounts.

Concerning sugar composition (Table 3), the five mushrooms showed some homogeneity. All of them presented mannitol and trehalose as main sugars. For A. arvensis, L. delicisosus and $S$. imbricatus mannitol was the most abundant sugar ranging from 0.07 to $1.38 \mathrm{~g} / 100 \mathrm{~g}$ of fresh weight (Fig. 1), while trehalose predominates in L. giganteus $(0.50 \mathrm{~g} / 100 \mathrm{~g})$ and $T$. portentosum $(1.46 \mathrm{~g} / 100 \mathrm{~g})$. The accumulation of these sugars in the fruit-bodies of Hypsizygus marmoreus (Peck) Bigelow (Harada et al., 2004), Agaricus bisporus Sing. (Minamide \& Hammond, 1985), Flammulina velutipes (Curt.: Fr.) (Kitamoto \& Gruen, 1976) and Lentinus edodes (Berk.) Sing. (Yang, Lin, \& Mau, 2001) has been already reported. With the exception of $A$. arvensis, other sugars were present either only in small amounts or were not detected.

Table 3

Sugar composition (g/100 g of fresh weight) of five Portuguese wild edible mushrooms (mean $\pm \mathrm{SD} ; n=3$ )

\begin{tabular}{|c|c|c|c|c|c|}
\hline & \multicolumn{5}{|l|}{ Mushrooms } \\
\hline & A. arvensis & L. deliciosus & L. giganteus & S. imbricatus & T. portentosum \\
\hline Mannitol & $0.33 \pm 0.00$ & $1.36 \pm 0.01$ & $0.14 \pm 0.00$ & $1.38 \pm 0.01$ & $0.07 \pm 0.00$ \\
\hline Trehalose & $0.02 \pm 0.01$ & $0.27 \pm 0.01$ & $0.50 \pm 0.00$ & $0.51 \pm 0.01$ & $1.46 \pm 0.03$ \\
\hline Total sugars & $0.35 \pm 0.01$ & $1.63 \pm 0.01$ & $0.64 \pm 0.00$ & $1.89 \pm 0.01$ & $1.53 \pm 0.03$ \\
\hline
\end{tabular}




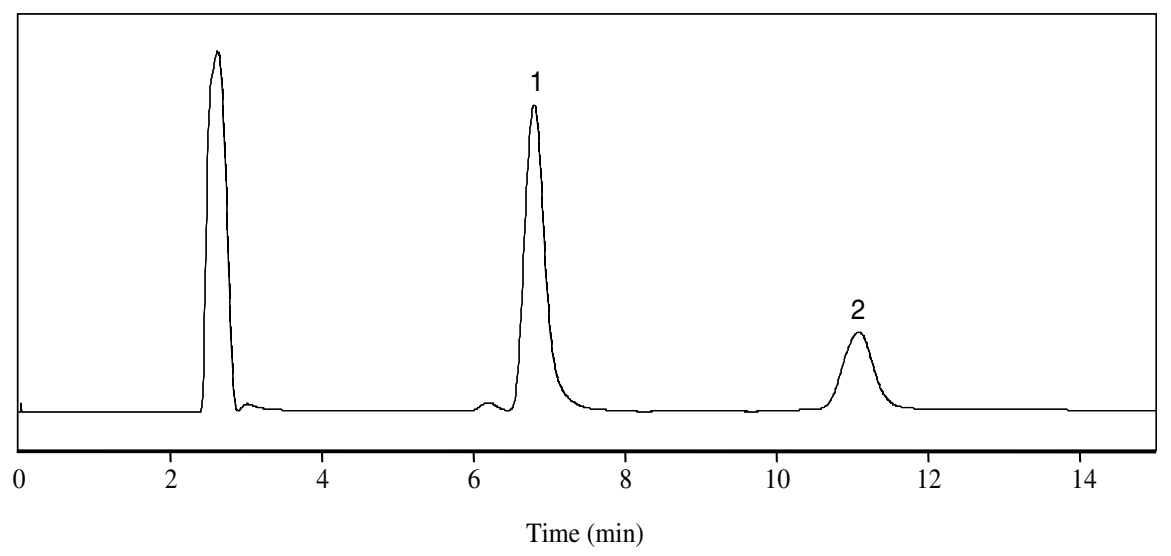

Fig. 1. Individual sugar chromatogram of Sarcodon imbricatus. 1 - mannitol and 2 - trehalose.

In conclusion, the chemical composition and energy values of the Portuguese wild edible mushrooms clearly indicate that they provide key nutrients such as protein, unsaturated fatty acids, and carbohydrates. Being a good source of protein and carbohydrate, they fall between most legumes and meat (FAO/WHO, 1989), and prove to be excellent foods that can be used in low caloric diets for their low contents of fat and energy. Nevertheless, the high nutritional quality and unique flavours of these mushrooms are likely to be lost if these wild edibles are not documented. Therefore, it is now imperative that a nutritional database of these mushrooms is set up to retain the information on these unique species and for a better management and conservation of this natural resource and habitats related to them.

\section{Acknowledgements}

The authors are grateful to Foundation for Science and Technology (POCI/AGR/56661/2004) for financial support of this work. The authors also thanks to Department of Analytical Chemistry, Nutrition and Bromatology of Salamanca University for ash determination.

\section{References}

Agahar-Murugkar, D., \& Subbulakshmi, G. (2005). Nutritional value of edible wild mushrooms collected from the Khasi hills of Meghalaya. Food Chemistry, 89, 599-603.

Aletor, V. A. (1995). Compositional studies on edible tropical species of mushrooms. Food Chemistry, 54, 265-268.

AOAC (1995). Official methods of analysis (16th ed.). Arlington VA, USA: Association of Official Analytical Chemists.

Barros, L., Calhelha, R. C., Vaz, J. A., Ferreira, I. C. F. R., Baptista, P., \& Estevinho, L. M. (in press). Antimicrobial activity and bioactive compounds of Portuguese wild edible mushrooms. European Food Research and Technology.

Barros, L., Ferreira, M.-J., Queirós, B., Ferreira, I. C. F. R., \& Baptista, P. (2007). Total phenols, ascorbic acid, $\beta$-carotene and lycopene in Portuguese wild edible mushrooms and their antioxidant activities. Food Chemistry, 103, 413-419.

Bobek, P., \& Galbavy, S. (1999). Hypercholesterolemic and anti-atherogenic effect of oyster mushroom (Pleurotus ostreatus) in rabbit. Nahrung, 45, 339-342.
Bobek, P., Ginter, E., Jurcovicova, M., \& Kunia, K. (1991). Cholesterollowering effect of the mushroom Pleurotus ostreatus in hereditary hypercholesterolemic rats. Annals of Nutritional Metabolism, 35, 191-195.

Bobek, P., Ozdyn, L., \& Kuniak, L. (1995). The effect of oyster (Pleurotus ostreatus) its ethanolic extract and extraction residues on cholesterol levels in serumlipoproteins and liver of rat. Nahrung, 39, 98-99.

Bon, M. (1988). In Guia de campo de los Hongos de Europa. Barcelona: Ediciones Omega.

Breene, W. M. (1990). Nutritional and medicinal value of specially mushrooms. Journal of Food Protection, 53, 883-894.

Courtecuisse, R. (1999). Mushrooms of Britain and Europe. London: HarperCollins Publishers.

Courtecuisse, R., \& Duhem, B. (1995). Mushrooms and toadstools of Britain and Europe. London: HarperCollins Publishers.

Crisan, E. V., \& Sands, A. (1978). Nutritional value. In S. T. Chang \& W. A. Hayes (Eds.), The biology and cultivation of edible fungi (pp. 727-793). New York: Academic Press.

Diéz, V. A., \& Alvarez, A. (2001). Compositional and nutritional studies on two wild edible mushrooms from northwest Spain. Food Chemistry, $75,417-422$.

FAO/WHO (1989). Protein quality evaluation. Report of the joint FAO/ WHO expert consultation. Food and Nutrition Paper no. 51. Food and Agriculture Organizations and the World Health Organization, Rome, Italy.

Fasidi, I. O. (1996). Studies on Volvariella esculenta (mass) Singer: Cultivation on agricultural wastes and proximate composition of stored mushrooms. Food Chemistry, 55, 161-163.

Ferreira, I. C. F. R., Baptista, P., Vilas-Boas, M., \& Barros, L. (2007). Free-radical scavenging capacity and reducing power of wild edible mushrooms from northeast Portugal. Food Chemistry, 100, 1511-1516.

Fink, H., \& Hoppenhaus, K. W. (1958). Peculiar observations in the estimation of biological quality of the proteins of edible boletus (Boletus edulis) and mushroom (Psalliato biospora) with reference to dietetics and therapeutics. Nutrition Abstracts Reviews, 28. Abs. 4886.

Flegg, P. B., \& Maw, G. (1977). Mushrooms and their possible contribution to world protein needs. Mushroom Journal, 48, 395-403.

Gruen, E. H., \& Wong, M. W. (1982). Distribution of cellular amino acids, protein and total inorganic nitrogen during fruit body development in Flammulina veluptipes. Canadian Journal of Botany, 60, 1330-1341.

Harada, A., Gisusi, S., Yoneyama, S., \& Aoyama, M. (2004). Effects of strain and cultivation medium on the chemical composition of the taste components in fruit-body of Hypsizygus marmoreus. Food Chemistry, $84,265-270$.

ISO 5509:2000 - Animal and vegetable fats and oils - preparation of methyl esters of fatty acids. 
Kitamoto, Y., \& Gruen, H. E. (1976). Distribution of cellular carbohydrates during development of the mycelium and fruitbodies of Flammulina velutipes. Plant Phytology, 58, 485-491.

Léon-Guzmán, M. F., Silva, I., \& López, M. G. (1997). Proximate chemical composition, free amino acid contents, and free fatty acids contents of some wild edible mushrooms from Queretaro, México. Journal of Agriculture and Food Chemistry, 89, 533-539.

Lindequist, U., Niedermeyer, T. H. J., \& Julich, W.-D. (2005). The pharmacological potential of mushrooms. Evidence-based Complementary and Alternative Medicine (eCAM), 2, 285-299.

Longvah, T., \& Deosthale, Y. G. (1998). Compositional and nutritional studies on edible wild mushroom from northeast India. Food Chemistry, 63, 331-334.

Maga, J. A. (1981). Mushroom flavour. Journal of Agriculture and Food Chemistry, 29, 1-4.

Manzi, P., Aguzzi, A., \& Pizzoferrato, L. (2001). Nutritional value of mushrooms widely consumed in Italy. Food Chemistry, 73, 321-325.

Manzi, P., Gambelli, L., Marconi, S., Vivanti, V., \& Pizzoferrato, L. (1999). Nutrients in edible mushrooms: An interspecies comparative study. Food Chemistry, 65, 477-482.

Manzi, P., Marconi, S., Aguzzi, A., \& Pizzoferrato, L. (2004). Commercial mushrooms: Nutritional quality and effect of cooking. Food Chemistry, 84, 201-206.

Marchand, A. (1971-1986). Champignons du Nord et du Midi, Tome 1-9. Perpignan: Soc Mycol Pyrénées Mediterranéenes.

Mauger, J.-F., Lichtenstein, A. H., Ausman, L. M., Jalbert, S. M., Jauhiainen, M., Ehnholm, C., et al. (2003). Effect of different dietary forms of dietary hydrogenated fats on LDL particle size. American Journal of Clinical Nutrition, 78, 370-375.
Minamide, T., \& Hammond, J. B. W. (1985). The influence of the periodic fruiting (flushing) cycle on the biochemical development of Agaricus bisporus sporophores. New Phytologist, 100, 571-578.

Moser, M. (1983). Keys to Agarics and Boleti (Polyporales, Boletales, Agaricales, Russulales). London: Roger Phillips.

Ogundana, S. K., \& Fagade, O. E. (1982). Nutritive value of some Nigerian edible mushrooms. Food Chemistry, 8, 263-268.

Senatore, F. (1990). Fatty acids and free amino acid content of some mushrooms. Journal of Science and Food Agriculture, 51, 91-96.

Senatore, F., Dini, A., \& Marino, A. (1988). Chemical constituents of some Basidiomycetes. Journal of Science and Food Agriculture, 45, 337-345.

Smith, J. (1972). Commercial mushroom production. Process Biochemistry, 7, 24-26.

Thimmel, R., \& Kluthe, R. (1998). The nutritional database for edible mushrooms. Ernahrung, 22, 63-65.

Valentão, P., Andrade, P. B., Rangel, J., Ribeiro, B., Silva, B. M., Baptista, P., et al. (2005). Effect of the conservation procedure on the contents of phenolic compounds and organic acids in Chanterelle (Cantharellus cibarius) mushroom. Journal of Agriculture and Food Chemistry, 53, 4925-4931.

Valentão, P., Lopes, G., Valente, M., Barbosa, P., Andrade, P. B., Silva, B. M., et al. (2005). Quantification of nine organic acids in wild mushrooms. Journal of Agriculture and Food Chemistry, 53, 3626-3630.

Yang, J.-H., Lin, H.-C., \& Mau, J.-L. (2001). Non-volatile taste components of several commercial mushrooms. Food Chemistry, 72, 465-471.

Yildiz, A., Karakaplan, M., \& Aydin, F. (1998). Studies on Pleurotus ostreatus (Jacq. Ex Fr.) Kum. Var. Salignus (Pers. Ex Fr.) Konr. et. Maubl.: Cultivation, proximate composition, organic and mineral composition of carpophores. Food Chemistry, 61, 127-130. 